\title{
Editorial
}

\section{The new WHO Global Air Quality Guidelines: What do they mean for South Africa?}

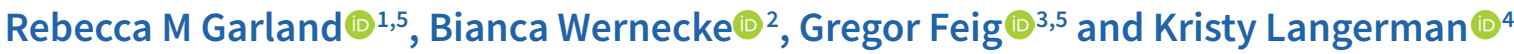 \\ ${ }^{1}$ Council for Scientific and Industrial Research, South Africa \\ 2South African Medical Research Council, South Africa \\ ${ }^{3}$ South African Environmental Observation Network (SAEON), South Africa \\ ${ }^{4}$ Department of Geography, Environmental Management and Energy Studies, University of Johannesburg, South Africa \\ ${ }^{5}$ Department of Geography, Geoinformatics and Meteorology, University of Pretoria, South Africa
}

https://doi.org/10.17159/caj/2020/31/2.12915

Ambient air quality standards are a key policy lever in air quality management. In South Africa, the introduction of the National Ambient Air Quality Standards (NAAQS) highlighted the shift in the focus of air quality management from source to receptor that was initiated with the introduction of the NEM:AQA. NAAQS were developed considering health impacts, ambient levels at the time and South Africa's developing economy. There is currently a process starting to review these standards, and this process aligns with the recent release of the new World Health Organization (WHO) Global Air Quality Guidelines (AQG) in September 2021 (World Health Organization, 2021). This is the first update of WHO's AQG since 2005. The WHO's guidelines take into account recent evidence of the effect of air pollution on human health, and many of the guidelines are substantially lower than the previous guidelines (Table 1 ). In this editorial, we ask what the implications of the new WHO Guidelines are for air quality management and compliance in South Africa.

\section{Overview of new guidelines}

The WHO's new guidelines recommend air quality levels for six pollutants based on their health effects, these are: particulate matter with an aerodynamic diameter smaller than $10 \mu \mathrm{m}$ and $2.5 \mu \mathrm{m}\left(\mathrm{PM}_{10}\right.$ and $\mathrm{PM}_{2.5}$, respectively), ozone $\left(\mathrm{O}_{3}\right)$, sulphur dioxide $\left(\mathrm{SO}_{2}\right)$, nitrogen dioxide $\left(\mathrm{NO}_{2}\right)$ and carbon monoxide $(\mathrm{CO})$. In addition to the guideline values, four interim target values are set as "incremental steps in a progressive reduction of air pollution." Interim targets 1-3 are the same as the interim targets

Table 1: A comparison between the South African National Ambient Air Quality Standards (2009 and 2012) and the WHO Air Quality Guidelines (WHO, 2006, WHO, 2021).

\begin{tabular}{|c|c|c|c|c|c|c|c|c|c|c|}
\hline \multirow[b]{2}{*}{ Pollutant } & \multirow[b]{2}{*}{$\begin{array}{l}\text { Averaging } \\
\text { time }\end{array}$} & \multirow[b]{2}{*}{ Unit } & \multicolumn{2}{|c|}{$\begin{array}{l}\text { South African National } \\
\text { Ambient Air Quality } \\
\text { Standard }\end{array}$} & \multirow[t]{2}{*}{$\begin{array}{l}\text { WHO Air } \\
\text { Quality } \\
\text { Guideline } \\
2005\end{array}$} & \multicolumn{5}{|c|}{ WHO Interim Targets (IT) and Air Quality Guideline (AQG) 2021} \\
\hline & & & Current & 1 Jan 2030 & & IT-1 & IT-2 & IT-3 & IT-4 & $\mathrm{AQG}$ \\
\hline \multirow{2}{*}{$\mathrm{PM}_{2.5}$} & 24 hours $^{\mathrm{a}}$ & $\mu \mathrm{g} / \mathrm{m}^{3}$ & 40 & 25 & 25 & 75 & 50 & 37.5 & 25 & 15 \\
\hline & 1 year & $\mu \mathrm{g} / \mathrm{m}^{3}$ & 20 & 15 & 10 & 35 & 25 & 15 & 10 & 5 \\
\hline \multirow{2}{*}{$\mathrm{PM}_{10}$} & 24 hours $^{\mathrm{a}}$ & $\mu \mathrm{g} / \mathrm{m}^{3}$ & 75 & n.c. & 50 & 150 & 100 & 75 & 50 & 45 \\
\hline & 1 year & $\mu \mathrm{g} / \mathrm{m}^{3}$ & 40 & n.c. & 20 & 70 & 50 & 30 & 20 & 15 \\
\hline \multirow[b]{2}{*}{$\mathrm{O}_{3}$} & 8 hours $^{b}$ & $\mu \mathrm{g} / \mathrm{m}^{3}$ & 120 & n.c. & 100 & 160 & 120 & - & - & 100 \\
\hline & $\begin{array}{l}\text { Peak } \\
\text { seasonc }\end{array}$ & $\mu \mathrm{g} / \mathrm{m}^{3}$ & - & - & - & 100 & 70 & - & - & 60 \\
\hline $\mathrm{SO}_{2}$ & 24 hours $^{\mathrm{a}}$ & $\mu \mathrm{g} / \mathrm{m}^{3}$ & 125 & n.c. & 20 & 125 & 50 & - & - & 40 \\
\hline \multirow[t]{2}{*}{$\mathrm{NO}_{2}$} & 24 hours $^{\mathrm{a}, \mathrm{d}}$ & $\mu \mathrm{g} / \mathrm{m}^{3}$ & - & - & - & 120 & 50 & - & - & 25 \\
\hline & 1 year & $\mu \mathrm{g} / \mathrm{m}^{3}$ & 40 & n.c. & 40 & 40 & 30 & 20 & - & 10 \\
\hline \multicolumn{11}{|c|}{$\begin{array}{l}{ }^{a} \text { At the } 99^{\text {th }} \text { percentile i.e. } 4 \text { allowed exceedance days per year } \\
{ }^{\text {b }} \text { At the } 99^{\text {th }} \text { percentile i.e. } 11 \text { allowed exceedance } 8 \text {-hour periods per year } \\
{ }^{c} \text { Average of daily maximum } 8 \text {-hour mean } \mathrm{O}_{3} \text { concentration in six consecutive months with the highest } 6 \text {-month running average } \mathrm{O}_{3} \text { concentration. } \\
\text { d South Africa has a } 1 \text {-hr NO} \mathrm{NO}_{2} \text { standard and not a } 24 \text {-hour standard } \\
\text { n.c. = no change } \\
-=\text { no value }\end{array}$} \\
\hline
\end{tabular}


in the 2005 WHO guidelines, and the fourth interim target is the 2005 air quality guideline (Table 1). The South African NAAQS for $\mathrm{PM}_{2.5}, \mathrm{PM}_{10}$ and $\mathrm{O}_{3}$ fall between the WHO interim targets 2 and 3, while the South African NAAQS for $\mathrm{NO}_{2}$ and $\mathrm{SO}_{2}$ align with the WHO interim target 1.

\section{Effective air quality management needs achievable goals}

The new $\mathrm{AQGs}$ for $\mathrm{PM}$ and $\mathrm{NO}_{2}$ are substantially lower than previous AQGs. This highlights that there is a risk to health at almost all exposure to these pollutants. We think this emphasizes the seriousness of poor air quality, and thus can be a motivation for focused swift action to improve air quality.

However, it has to be acknowledged that the WHO AQG levels are not attainable in many areas of the world, including many parts of South Africa. This is due in part to the many strong and varied natural sources of pollution (including dust, biomass burning, biogenic and marine sources) in South Africa. The impact of natural sources on air pollution levels is a key research gap. Long term observations in background sites, as initially envisaged in the 2012 Framework for Air Quality Management (RSA, 2012), are important to better understand these sources. Robust modelling experiments to estimate the contribution of natural sources to background levels across South Africa are also a critical piece of the puzzle that must be considered in the review of the NAAQS and setting of standards.

The great difference between the current pollution levels in South Africa and the NAAQS limits on the one hand, and the new WHO AQGs on the other hand, can be disheartening, as these targets may seem unachievable. However, urgent action to reduce air pollution levels is needed, as there are many places in South Africa where the ambient air pollution concentrations do not meet the NAAQS (e.g., Feig et al., 2016; Feig et al., 2019; Govender and Sivakumar, 2019; Hersey et al., 2015; Venter et al., 2012). Any improvement in air quality will have a positive impact on health.

South Africa's NAAQS will continue to be our country's benchmark in air quality management and compliance. The WHO guidelines and interim targets are one of many aspects that need to inform our national standards. Effective air quality management needs achievable goals, and thus, the WHO's interim targets can play an important role in South Africa's standards setting.

\section{References}

Feig, G.T., Naidoo, S., Ngcukana, N. (2016), Assessment of ambient air pollution in the Waterberg priority area 2012-2015 Clean Air Journal, 26(1) pp 21-28 http://dx.doi.org/10.17159/2410972X/2016/v26n1a9

Feig, G.T., Garland, R.M., Naidoo, S., Maluleke, A., van der Merwe, M. (2019) Assessment of changes in concentrations of selected criteria pollutants in the Vaal and Highveld priority areas, Clean Air Journal, 29(2) doi: 10.17159/caj/2019/29/2.7464.

Hersey, S.P, Garland, R.M., Crosbie, E., Shingler, T., Sorooshian, A., Piketh, S., Burger, R. (2015) An overview of regional and local characteristics of aerosols in South Africa using satellite, ground and modelling data, Atmospheric Chemistry and Physics, 15, 4259-4278, doi: 10.5194/acp-15-4259-2015.

Govender, K., Sivakumar, V. (2019). A decadal analysis of particulate matter $\left(\mathrm{PM}_{2.5}\right)$ and surface ozone $\left(\mathrm{O}_{3}\right)$ over Vaal Priority Area, South Africa. Clean Air Journal, 29(2). https://doi. org/10.17159/caj/2019/29/2.7578

Republic of South Africa, The 2012 National Framework for Air Quality Management in the Republic of South Africa. Available at: https://www.dffe.gov.za/sites/default/files/gazetted_notices/ nema_national_framework_aqm_gn115_0.pdf

Venter, A.D., Vakkari, V., Beukes, J.P., et al. (2012) An air quality assessment in the industrialised western Bushveld Igneous Complex, South Africa. S Afr J Sci.;108(9/10), http://dx.doi. org/10.4102/sajs.v108i9/10.1059

World Health Organization. Regional Office for Europe. (2006). Air quality guidelines: global update 2005: particulate matter, ozone, nitrogen dioxide and sulfur dioxide. World Health Organization. Regional Office for Europe. https://apps.who.int/ iris/handle/10665/107823

World Health Organization. (2021). WHO global air quality guidelines: particulate matter $\left(\mathrm{PM}_{2.5}\right.$ and $\left.\mathrm{PM}_{10}\right)$, ozone, nitrogen dioxide, sulfur dioxide and carbon monoxide. World Health Organization. https://apps.who.int/iris/handle/10665/345329. License: CC BY-NC-SA 3.0 IGO 